\title{
Comunicación, Información y Conflictos: Las Imágenes de la Guerra en la Guerra De Las Miradas
}




\section{Resumen}

No es posible comprender la historia moderna de los medios de comunicación sin analizar las guerras que se han sucedido a lo largo de los años, es decir, son historias paralelas que se encuentran en muchos momentos. Hoy la situación cambia en la medida en que los medios son las propias armas de guerra, de ahí la idea de que las guerras se producen entre los medios. Esta situación implica que el programa político-estético de algunas vanguardias y la estetización de la política propugnada por el fascismo, se radicaliza. Más que frente a la sociedad del espectáculo, a las industrias culturales o a la cultura masiva, nos encontramos frente a la estetización tecnocultural de la guerra.

\section{Palabras claves}

medios de comunicación - guerras- historia- rizomas- redes- estéticaimágenes.

\section{Abstract}

It is not possible to understand the modern history of the communication media without analyzing the wars that have succeeded each other throughout the years; which means, they are parallel histories that meet many times. Nowadays the situation changes as the media themselves are the war weapons; that's why the idea that the wars are produced among the media has been developed.

\section{Key words}

Communication media- wars- history- rhizomes- nets. 
"Indra, el dios guerrero, se opone tanto a Varuna [rey y mago] como a Mitra [sacerdote y legisiador]. No se reduce a una de los dos, ni tampoco forma una tercera. Más bien sería como la multiplicidad pura y sin medida, la manada, irrupción de lo efimero y potencia de la metamorfosis. Deshace el lazo en la misma medida en que traiciona el pacto. Frente a la mesura esgrime un furor, frente a la gravedad una celeridad, frente a lo público un secreto, frente a la soberania una potencia, frente al aparato una máquina"

Gilles Deleuze y Félix Guattari. Mil mesetas: capitalismo y esquizofrenia.

\section{I- Crisis de la representación: ¿la desaparición del otro?}

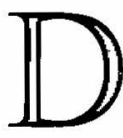

espués de Auschwitz ya no es posible representar al otro, relatarlo, en definitiva, nominarlo para nombrarlo. Se abre una nueva discontinuidad en el debate que ha acompañado toda la historia de Occidente sobre la "naturaleza" o "arbitrariedad" de los nombres propios. Por acercarnos a uno de los "desgarrones" de esa larga historia, hay que considerar que en el Crátilo el diálogo adquiere el "juego" de tomas de posiciones entre Hermógenes, Crátilo y Sócrates, sobre si cada uno de los seres tiene el nombre exacto por naturaleza (Platón, 1988: 364). En la modernidad, otra de las fracturas y emergencias de Occidente, "las palabras y las cosas" (parafraseando la ironía planteada por Michel Foucault, 1986), se separan y se reafirma la perdida de transparencia entre ambas, ingresando la representación en una crisis profunda, en una línea sin intentar ser evolucionista- que se encuentra con la crisis de la representación planteada por algunas vanguardias artísticas (entre ellas, el surrealismo, el dadaísmo o el futurismo) y otra crisis, más radical aún, propiciada por los simulacros mediáticos. 
Esa crisis de la representación (que cruza todo el debate metafísico occidental1), después de Auschwitz, dejó sin efecto el optimista e "ideológico" criterio de que la paz "sería superior a si misma y la guerra menos mala" (Viscardi, 2005: 19). Esa reflexión sobre Auschwitz y el totalitarismo atraviesa los trabajos de la Escuela de Frankfurt y, como escribe Ricardo Viscardi (2005: 20- 21), "motiva la reacción anticomunista de mediados de los ' 60 , inspira las mejores reediciones del liberalismo y lanza al post- 68 en una vía ética que renueva la filosofía por la senda perdida postestructuralista y postanalítica, para cristalizar finalmente en la postmodernidad". En ese sentido, Art Spliegelman, creador del cómics Sin la sombra de las torres (sobre la destrucción de las torres gemelas), reinterpreta la frase de Adorno sobre la imposibilidad de hacer poesía después de Auschwitz, incorporando un matiz: "en realidad, lo que no se puede hacer es escribir poesía mala". También, la reflexión sobre Auschwitz y el totalitarismo, dejó por el camino, los planteamientos sobre la "ideología de la comunicación" (con umbrales como los de la cibernética o la teoría matemática de la información), que planteaban la renovación del hombre moderno. 'Un 'hombre nuevo', capaz de integrarse armónicamente en un orden social dedicado a la circulación de información, comandada por máquinas de comunicar" (Muniz Sodré, 1998: 48). Así, la cibernética surgía como respuesta frente a las consecuencias que traería aparejada la segunda ley de la termodinámica por la pérdida gradual o progresiva de energía en un sistema. Por tanto, había que reducir la entropía como medida contraria al orden, como fuerza permanente de destrucción o desorden. Es decir, había que restituir el sistema, que, en definitiva,

1. Para Jacques Derrida (1989a: 107), que "la filosofia haya muerto ayer, después de Hegel o Marx, Nietzsche o Heidegger", "o que haya vivido siempre de saberse moribunda", "que haya muerto un día, en la historia, o que haya vivido siempre de agonia y de abrir violentamente la historia arrancándole su posibilidad contra la no filosofía, su fondo adverso, su pasado o su facticidad, su muerte y su recurso", quizás, incluso gracias a ellas, "el pensamiento tenga un porvenir o incluso" esté todo él por venir...", "todas estas cuestiones no son capaces de respuesta. Son, por nacimiento y por una vez al menos, problemas que se plantean a la filosofía como problemas que ella no puede resolver". 
era un sistema de pensamiento. Sin embargo, más allá de los intentos, el exterminio había llegado al pensamiento "como consecuencia del exterminio en el relato" (Viscardi, 2005: 20). Así, se había quebrado "la base sistemática de cualquier sistema" que se supusiera "real en el sentido de la correspondencia recíproca", entre el sistema y el pensamiento, porque como planteaba Derrida (1977), todo sistema era (y es) ante todo "un sistema de pensamiento". Por tanto, después de Auschwitz se establece la interrogante sobre si es posible pensar, aunque esa formulación en términos de pregunta no tuviera una respuesta posible, ya que -siguiendo a Derridason problemas que se le plantean "a la filosofía" (o al arte) "como problemas" que ellos no pueden resolver" (Derrida, 1989a: 108). No obstante, hay intentos de problematizar esas interrogantes y de plantearse la urgencia en el pensar después del intento de destrucción del otro (es decir, de la característica dialógica del relato). Frente a la parálisis surgen preguntas y acciones que intentan responderlas. Esa urgencia fue la que motivó que un artista de comics como Art Spiegelman -integrante de la literatura del holocausto-, que después de creaciones como Maus ${ }^{2}$ se había apartado del comics, luego del atentado y la destrucción de las torres gemelas, volviera a crear entre los escombros y la destrucción. Comenta: "me prometí que sólo volvería a hacer comics porque me parecía que era lo único que podía hacer en relación a la situación del planeta" luego del 11-s, "mientras otros esperaban el fin del mundo", él paralizado intentaba volver a crear, y después de un tiempo y del shock inicial, publicó el libro Sin la sombra de las torres. Su obra es un objeto extraño, algo así como un diario impresionista en cámara lenta hecho por un vecino del bajo Manhattan (Costa, 2005: 58).

2. La materia prima de Maus (perteneciente a la llamada literatura del Holocausto) son las experiencias de los judios en los campos de concentración nazis, un relato en dos volúmenes donde los judios aparecen como ratones y el ejército alemán como gatos. Ganó el premio Pulitzer en 1992. 


\section{II - Crisis de la representación y estetización de la guerra}

Esa crisis de la representación que, como señalábamos, cruza toda la historia metafísica occidental, para algunos pensadores, después de Auschwitz, y de ese intento de exterminio del otro, adquirió otra tonalidad. Uno de ellos es François Lyotard (1996), quien plantea la noción de diferendo como radicalización de la diferencia. El diferendo, después de Auschwitz, se vuelve irresoluble en la medida en que no hay posibilidades de zanjar el conflicto equitativamente "por faltar una regla de juicio aplicable a la dos argumentaciones". Que una de ellas sea legítima no implica que la otra no lo sea. Es decir, después de Auschwitz, la representación -tal como señala Paul Virilio (1998: 18)- padece una crisis sin precedentes que no tiene "ninguna relación con ningún tipo de decadencia clásica". En ese sentido, Hermann Raushning en noviembre de 1939, hablaba del "hundimiento universal de todo orden establecido, algo que la memoria del hombre jamás había visto" (en Virilio, 1998: 18).

Es interesante constatar que esa crisis de la representación que estamos analizando desde el desgarrón que significó Auschwitz, como programa político/ estético, se encuentra con la reflexión de Walter Benjamin sobre la estetización de la política propiciada por el nazismo, $\mathrm{y}$, con algunos de los postulados y programas de las vanguardias estéticas. Es así como antes de la primera guerra mundial, fueron los futuristas ${ }^{3}$ los primeros que articularon el culto de la guerra como forma estética. Así las cosas, esta vanguardia estrechaba las relaciones entre arte y fascismo, glorificando la guerra y estetizándola. En el primer manifiesto futurista se la glorificaba, considerándola como la "única higiene del mundo", así como "el militarismo, el patriotismo, el gesto destructor de los libertarios, las bellas ideas por

3. "Marinetti, corresponsal de guerra en Libia, que se inspiraba en la transmisión telegráfica, como por otra parte en todo tipo de amnesia topográfica, y explosivos, proyectiles, aviones, vehículos rápidos... para redactar poemas (...) En Italia habian sido los inspiradores de los movimientos anarquista y fascista, y Marinetti era amigo personal del Duce" (Virilio, 1998: 23). 
las cuales" se moría y “el desprecio de la mujer". En otro manifiesto posterior de Marinetti sobre la guerra colonial de Etiopía, se llegaba a decir que los futuristas se alzaban contra la idea de que la guerra era antiestética. Así, reafirmaban que "la guerra" era "bella, porque, gracias a las máscaras de gas, al terrorífico megáfono, a los lanzallamas y a las tanquetas", fundaba "la soberanía del hombre sobre la máquina subyugada". Era bella, porque inauguraba "el sueño de la metalización del cuerpo humano" y enriquecía "las praderas florecidas con las orquídeas de fuego de las ametralladoras". La guerra era bella, porque reunía "en una sinfonía los tiroteos, los cañonazos, los altos el fuego, los perfumes y olores de la descomposición". La guerra era "bella, porque creaba "arquitecturas nuevas como la de los tanques, la de las escuadrillas formadas geométricamente, la de las espirales de humo en las aldeas incendiadas y muchas otras". Finalmente proclamaba: “Poetas y artistas futuristas... acordaos de estos principios fundamentales de una estética de la guerra para que illuminen vuestro combate por una nueva poesía (...) por unas artes plásticas nuevas!".

Era la estetización del fascismo o, mejor dicho, la introducción de la estética en la vidla política, como le llamó Walter Benjamin, al final de su célebre ensayo: La obra de arte en la época de la reproductibilidad técnica. Walter Benjamin decía: Fiat ars- pereat mundus, proclamaba el fascismo, y esperaba "que la guerra" proporcionara "la gratificación artística de una percepción sensorial alterada por la tecnología". Esto es: "la perfección del arte por el arte". La humanidad, que antiguamente, en Homero, "era un objeto de espectáculo para los dioses olímpicos", se había convertido "en espectáculo de sí misma" (Benjamin, 1987). Su autoalienación, decía Benjamin, (y observen los lectores que actuales sus palabras): había "alcanzado un grado que" le permitía "vivir su propia destrucción como un goce estético de primer orden". Este era el esteticismo de la política que el fascismo propugnaba.

Hoy, muchos "eventos" (como las dos guerras del Golfo, el atentado a las torres gemelas) se analizan en diversos escritos, como "espectáculos" estéticos, como una extensión ilimitada de la imagen ya transformada en simulacro. Así las cosas, el critico de la cultura 
George Yudice, analiza en "el terror de la cultura global", publicado en el 2005, los diversos intentos de reconstituir lugares para la conmemoración. Para Yudice, esos intentos de conmoración se dan, porque, por una parte, el ser humano tiene necesidad de duelo"; y, por otra, porque "le provoca el lado oscuro del espíritu humano que impulsa a transformar estos acontecimientos en escenarios no sólo de conmemoración sino de consumo y rentabilidad" (Yudice, 2005: 6). En definitiva, son la cara actual de los memoriales, que mezclan conmemoración, lucro y espectáculo (estética). Los memoriales "atraen un turismo del sufrimiento" (término que ya se encuentra incluido en el diccionario Mac Millan), así como, paralela y paradójicamente, son embellecidos para los turistas. Como dijo el alcalde de Phonm Penh al inaugurar el memorial Choeung Ek que recuerda las 17 mil víctimas de Pol Pot y el Khmer Rojo: "este proyecto mejorará el turismo en el país, pues no sólo se visitarán templos históricos, sino que se buscará ver con los propios ojos la violencia de los campos de muerte". No obstante, estos recursos no son novedosos, como escribe George Yudice (2005: 6), lo que caracteriza a esta época, es "la continuidad entre escenificación y comercialización del sufrimiento". Y en este punto nos encontramos con la llamada por Eduardo Subirats (2001: 38- ss): violencia sígnica que producen los simulacros (escenificación de la violencia, por ejemplo) al vaciar referencialmente a los signos, llevando al extremo un programa que ya había comenzado a formularse -como señalábamos- con las vanguardias del siglo que acaba de terminar, tal como lo exponíamos con el ejemplo del futurismo. Más de medio siglo después del manifiesto futurista, la Guerra del Golfo Pérsico tuvo un valor "estético", espectacular" y simulado: fue la primera guerra concebida integramente como "evento" mediático. Una guerra de simulacros, montada electrónicamente y destructora de cualquier tipo de experiencia inmediata. Es la pasiva conformidad del tono insensible, desafectivizado, de las redes mediáticas y de la

4. Entiéndase que nos referimos a estético, considerando el análisis que Benjamin realiza sobre el fascismo, y, "espectacular" en el sentido de Guy Debord (1990 y 1999). 
administración de la "pobreza de la experiencia" (Benjamin), es decir, de una actualidad tecnológica sin piedad ni compasión que fragiliza los restos de la memoria herida. Benjamin decía que "la cotización de la experiencia", había caído y parecía seguir cayendo libremente al vacío. Señalaba que bastaba echar una mirada a un periódico para corroborar que había alcanzado una nueva baja, que tanto la imagen del mundo exterior como la del ético, estaban sufriendo de la noche a la mañana, transformaciones que jamás se hubieran considerado posibles. El punto de inflexión para Benjamin era la Guerra Mundial y se preguntaba si no se notaba acaso que la gente volvía enmudecida del campo de batalla. "En lugar de retornar más ricos en experiencias comunicables, volvían empobrecidos. Todo aquello que diez años más tarde se vertió en una marea de libros de guerra, nada tenía que ver con experiencias que se transmiten de boca en boca". Y eso no era sorprendente, pues jamás las experiencias resultantes de la refutación de mentiras fundamentales, significaron un castigo tan severo "como el infligido a la estratégica por la guerra de trincheras, a la económica por la inflación, a la corporal por la batalla material, a la ética por los detentadores del poder". Una generación que todavía había ido a la escuela en tranvía tirado por caballos, se encontró súbitamente a la intemperie, en un paisaje en que nada había quedado incambiado a excepción de las nubes. Entre ellas, rodeado por un campo de fuerza de corrientes devastadoras y explosiones, se encontraba el minúsculo y quebradizo cuerpo humano".

Por tanto, las guerras del Golfo, siguiendo esas ideas benjaminianas y el planteamiento que venimos sosteniendo, fueron conflictos bélicos concebidos estéticamente como simulacros. Una estética concebida a gran escala, tal como fue formulada por los pioneros mediáticos del nacional socialismo alemán. "La dictadura de Hitler (...) fue la primera (...) del presente período de desarrollo técnico moderno, una dictadura que hizo un uso completo de todos los medios técnicos para la dominación de su propio país", decía Albert Speer, en el proceso a que fue sometido después de la segunda guerra mundial. El mismo Speer era el que había diseñado los efímeros estadios de luces para los actos de Adolf Hitler. Speer - coordinador de los festejos nazis del Zeppelín- Feld y teórico del valor de las 
ruinas- elaboró para el congreso del Partido en Nuremberg, una estructura conformada por ciento cincuenta proyectores, cuyos haces, dirigidos verticalmente hacia el cielo, formaba un rectángulo de luz en la noche. "Precisamente en el interior de esos muros luminosos, los primeros de ese tipo, se desarrolla el congreso con todo su ritual (...) Experimento ahora una curiosa impresión ante la idea de que la creación arquitectónica más conseguida de mi vida haya sido una fantasmagoría, un espejismo irreal", señalaba Speer. Los militantes nazis, como plantea Goebbels, siguiendo ideas de la propaganda y del psicoanálisis, "obedecen a una ley que ni siquiera conocen pero que podrian recitar incluso en sueños" (en Virilio, 1998: 22). Aldous Huxley, años después, señala que desde Hitler, "el arsenal de elementos técnicos a disposición de un presunto dictador ha aumentado mucho" (1960: 63), mientras que Guy Debord (1998) define a esa situación como la sociedad del espectáculo concentrado. Tiempo después, Debord se refiere al espectáculo integrado, que implica que el poder ya no está concentrado ni centralizado sino diseminado, y, Huxley (1960: 63) señala: "gracias al progreso tecnológico, el Gran Hermano puede actualmente ser casi tan ubicuo como Dios". Lo "espectacular integrado" se relaciona con esa "guerra civil preventiva" (Debord), "protagonizada por entramados massmediáticos que son sólo el rostro amable de un nuevo poder concentrado y a la vez difuso" (Méndez Rubio, 2003: 83). Si bien es cierto que el planteamiento de Debord, es determinista, mecánico, alienante y parece cerrarse sobre sí mismo, no es menos cierto, que permite analizar, desde la concepción del espectáculo, el pasaje de la sociedad espectacular (de la radio, por ejemplo) al "simulacro" (Baudrillard) de sociedad y cultura, donde la técnica manufactura imágenes pero, también, emociones desde la virtualidad digital. Ya no hay alienación, por tanto, no hay espectáculo, sino similitudes y simulacros.

Es así que el "cronotopo" (Bajtin) desde el que los sujetos se ubicaban espacio- temporalmente en el mundo, deja paso a la "cronoscopía" donde lo que prima es la exposición o sobreexposición imagónica; la "exhibición" o sobre exhibición. Por tanto, la relación con el tiempo comienza a relacionarse con "ese tiempo de exposición que deja ver o que ya no permite ver" (Virilio, 1998: 79). Esta 
concepción del tiempo se ha radicalizado en los conflictos contemporáneos donde su valor es, fundamentalmente, de "exposición" y exhibición.

Así las cosas, los vídeos instalados en los propios misiles, en las guerras actuales o en la actualidad de la guerra, definen la estetización de la guerra. El mismo dispositivo técnico filma de un lado, lo que destruye por el otro. En una sincronía de instrumentos: los medios técnicos de clestrucción coinciden con los medios plásticos de su reproducción audiovisual y componen una identidad de los medios, del espectáculo electrónico y de la muerte. Quizás se está cumpliendo definitivamente la "síntesis futurista de la guerra", 5 que se refiere a la confluencia de lo estético y de lo militar y que no afecta solamente las estrategias performativas de la guerra, sino que ella significa, antes que nada, una identidad de las miradas (Subirats, 2001: 43).

El espectador de televisión y los instrumentos de destrucción coinciden en un mismo formato perceptivo, proceso cognitivo y, en definitiva, en el mismo objetivo letal. Los ojos de los sujetos espectadores (ya transformados en guerreros) delante de la pantalla de televisión se confunden con la imagen creada por los rayos laser, a través del cual el video detecta un objetivo, guía o misil, ejecuta la destrucción mediante un proceso electrónico automatizado.

Eduardo Subirats (2001: 44- ss) señala tres características de estos procesos de guerra de las miradas: la primera es la guerra y su agonía convertidas en obra de arte técnicamente producida. La segunda, es la composición visual fragmentaria en el sentido de las técnicas del collage y del montaje desarrolladas por las vanguardias

5. En 1915 fue acuñado el concepto de guerra pintura en el manifiesto de Carlo Carrà que lleva ese título (en Subirats, 2001: 43). Virilio señala que "sin duda exponian con demasiada claridad esa convergencia de las técnicas de comunicación y el totalitarismo en vías de constitución ante 'esos ojos ungidos por lo nuevo' -ojos futuristas, cubistas, interseccionistas, que no cesan de agitarse, de adsorber, de irradiar toda la belleza espectral, transferida, sucedànea, toda esa belleza sin soporte, dislocada, emergida"' (de Action poétique, 110, invierno de 1987. "Pessoa et le futurismo portugais" en Virilio, 1998: 23). 
dadaístas, cubistas y surrealistas. Así, la reproducción audiovisual de la guerra fractura cualquier relación intrínseca o causal entre las imágenes de las máquinas de destrucción, partiendo rumbo a sus objetivos, las visiones de ruinas y las situaciones aisladas de desolación humana. La tercera característica es la descontextualización de la imagen, con referencia a su objeto, $\mathrm{y}$, su recontextualización, acto seguido, en un sistema de señales corporativamente manufacturadas. La cuarta es la guerra como "video game", lo que lleva a participar de ella como si de un juego electrónico se tratara. Estas características nos llevan a referirnos, junto con Muniz Sodré (1998: 9), a un momento "tecnocultural", y ya no de cultura de masas o de industria cultural, en la medida en que "las imágenes estetizantes se dispersan por todas partes", no reduciéndose simplemente a una zona especial llamada industria, ni a partir de un público especial llamado "de masas". No se vive más que de apariencias, de "una superficie de imágenes; por eso mismo puede acaso agradar", escribia Borges en el prólogo a la edición de 1954 de Historia universal de la infamia.

\section{III- Las máquinas de guerra}

La tecnocultura que estetiza también a la guerra, se conforma más que por ejércitos por las "máquinas de guerra", tal como Gilles Deleuze y Félix Guattari (2000) plantearon este concepto. Esa máquina se presenta bajo dos figuras: en primer término la del fascismo que transforma a la guerra en un movimiento ilimitado cuya finalidad única es él mismo; "pero el fascismo no es más que "esbozo"'. De ahí la segunda figura que es la posfascista, de una máquina de guerra que toma directamente la paz por objeto, como paz del Terror o de la Supervivencia" (Deleuze y Guattari, 2000: 421). El Imperio en sus últimas incursiones bélicas ha poblado el planeta de llamadas "operaciones de paz": Haití, es uno de los últimos casos en el continente americano. Estas incursiones de paz, no son más que nuevas guerras disfrazadas (trasvestidas) de pacificación universal. Esa estetización de la política, a la que nos estamos refiriendo, y, que implicó el giro cultural de la política, culmina -en el caso de la comunicación- en estetización de la información mediática 
una vez que, medio siglo más tarde, lo mediático terminó de absorber los últimos residuos de lo político. "Las realidades comunicacionales contenidas en expresiones ya clásicas se ven rápidamente modificadas por el advenimiento de nuevas tecnologías de la información" (Muniz Sodré, 1998: 10), que cuestionan el estatuto de la presencia y de lo real. "La escena se llena con una colección de actuaciones desinsertadas, de poses falsas, de impostaciones de la voz, de mímicas discursivas, de frases mentirosas: todo un juego de apariencias destinado a compensar el debilitamiento del significado (histórico, político) con una proliferación exhibicionista de significantes vistosos", escribe Nelly Richard (1998: 60). Así, se debilita la connotación (Barthes, 1989: 6- ss.) y se extienden por la superficie acciones denotadas sin más profundidad que la de la pantalla.

Son las guerras de las imágenes, mediáticas, virtuales y simuladas. Cualquier transeúnte puede ser víctima pero también victimario. "El rizoma conecta un punto con otro punto cualquiera...", escribían Deleuze y Guattari $(1980,2000)$. Y siguen considerándolo: asignificante, sin general, ni memoria organizadora o "autónomo central", "definido únicamente por una circulación de estados". En esta circulación de estados potenciales, nos encontramos con los nocuerpos de las guerras contemporáneas y su desaparición, transformados, como en las vanguardias, en estética. Es el abandono del mundo material y el ingreso a la virtualidad. Volvemos a la idea de Benjamin sobre el fascismo, de que se vivía la destrucción como sí de un goce estético de primer orden se tratara. Es el caso del fotógrafo Bill Biggart, muerto sobre los escombros de las Torres Gemelas del World Trade Center, ya sin cuerpo, convertido en una virtualidad al entrar en la imagen y, al mismo tiempo, morir con ella. Las fotos digitales (guerra numérica, simulada) fueron el testimonio de su entrada en la virtualidad. Biggart fue al (no) lugar de los ataques minutos antes que ocurriera el desmoronamiento de la segunda torre, de sus tres cámaras carbonizadas (dos analógicas y una digital) fueron rescatadas las imágenes de la cámara digital porque las fotografías de las dos cámaras analógicas habían sido destruidas por los efectos del desastre. Por tanto, se transformó en un simulacro devorado por sus propias virtualidades imagónicas. Las imágenes de Biggart son 
similitudes, copias de copias, la expansión de la copia sin vuelta al origen (diseminación).

\section{IV- Las miradas transformadas en imágenes}

De esa forma, la nihilista "muerte de Dios" nietzscheana, se extendió hacia la muerte del hombre con Foucault y Deleuze y ahora se ubica en la radical crisis de la civilización occidental a la que Baudrillard se refiere como ex occidente, en la medida en que ha perdida todos sus valores propios, que se sostuvieron por su tradición. Las guerras que a históricamente adquieren un carácter permanente, en esta compleja contemporaneidad, no son más que un paso en la radical crisis de Occidente. Esa crisis fue precedida por el nihilismo, el inquietante huésped que se hallaba en la puerta, como lo calificó Nietzsche.

No es posible aislar la historia de Occidente del nihilismo. Es así, que el ocaso contemporáneo de Occidente (que se puede ejemplificar en acontecimientos concretos que han desgarrado el proyecto occidental como el atentado a las Torres Gemelas, las dos guerras de Irak, la guerra de Afganistán, los atentados de Madrid y Londres) va a la par del ocaso de las imágenes y de las miradas que paralelamente se convertían en imágenes. Por tanto, no hay que confundir el nihilismo ("el destino de dos milenios de historia occidental", como lo conceptualiza Heidegger) con sus manifestaciones o consecuencias. Si el nihilismo es la desvalorización de todos los valores superiores, las muertes de Dios y el Hombre, son las muertes de todo un proyecto civilizatorio.

La comunicación, potenciada por la nihilista visualidad de las técnicas de la comunicación y de la información, al igual que Dios, el Hombre, la representación y la variante de ambos el autor, está en crisis por exceso. Extasiada por el simulacro mediático, angustiada ante la emancipación del otro, muere por exceso de transparencia, por opacarse la copia que busca alguna referencia donde anclarse. Se ha radicalizado la inversión del platonismo, sus temores al simulacro se cumplen. La idea del catolicismo de que Dios hace al hombre a su imagen y semejanza, por el pecado pierde la semejanza y queda sólo transformada en imagen. "Nos hemos convertido en simulacros (...) hemos entrado en la existencia estética" (Deleuze, 1989: 259). 


\section{Bibliografia}

BARTHES, Roland. S/ Z, México. siglo XXI, 1989.

BAUDRILLARD, Jean. El crimen perfecto. Barcelona: Anagrama, 1996.

BENJAMIN, Walter. Discursos interrumpidos. Madrid: Taurus, 1987.

BORGES, Jorge Luis. "Prólogo a la edición de 1954" de Historia universal de la infamia, Madrid: El País, 1995.

COSTA, Flavia. "Diario impresionista en cámara lenta sobre el 11S", entrevista a Art Spiegelman, en $\tilde{N}$, Buenos Aires: Clarín, 2005.

DEBORD, Guy. Comentarios sobre la sociedad del espectáculo. Barcelona:Anagrama, 1990.

. La sociedad del espectáculo. Valencia:Pre- textos, 1999.

DERRIDA, Jacques. Posiciones. Valencia, Pre- textos, 1977.

. La escritura y la diferencia. Barcelona: Anthropos, 1989a.

. Márgenes de la filosofia. Madrid: Cátedra, 1989b.

HEIDEGGER, Martín. Caminos de bosque. Madrid: Alianza, 1995.

HUXLEY, Aldous. Nueva visita a un mundo feliz. Barcelona: Sudamericana, 1960.

LYOTARD, Jean François. La diferencia. Barcelona:Gedisa, 1996.

MARINETTI, Filippo Tommaso. Teoria e invenzione futurista. Milan: Mondadori, 1968.

MÉNDEZ RUBIO, Antonio. La apuesta invisible. Cultura, globalización y crítica social. Barcelona: Montesinos, 2003.

MUNIZ SODRÉ. Reinventando la cultura. La comunicación y sus productos. Barcelona:Gedisa, 1998.

PLATÓN. Diálogos. Madrid, Espasa Calpe: Austral, 1998.

RICHARD, Nelly. Residuos y metáforas. (Ensayos de crítica cultural sobre el Chile de la transición), Santiago:Cuarto Propio, 2001.

SUBIRATS, Eduardo. A penúltima visão do Paraíso, ensaios sobre memória e globalização. São Paulo:Nobel, 2001. 
YUDICE, Geoge: "El terror en la cultura global", en $\tilde{N}$, Buenos Aires: Clarín, 27 de agosto, 2005.

VISCARDI, Ricardo. Guerra en su nombre. Los medios de la guerra en la guerra de los medios, Sevilla:Arcibel, 2005.

VIRILIO, Paul. La máquina de visión, Madrid: Cátedra, 1998. 